Köhl et al.

Running title: mycorrhizal effects on nutrient leaching

\title{
Arbuscular mycorrhizal fungal species differ in their effect on nutrient leaching
}

Luise Köhl ${ }^{1,2}$ and Marcel G.A. van der Heijden ${ }^{1,2,3}$

${ }^{1}$ Plant-soil-interactions, Institute for Sustainability Sciences, Agroscope, CH-8046 Zurich, Switzerland

${ }^{2}$ Plant-microbe Interactions, Institute of Environmental Biology, Faculty of Science, Utrecht University, 3508 TB Utrecht, The Netherlands

${ }^{3}$ Institute of Evolutionary Biology and Environmental Studies, University of Zurich, CH-8057 Zurich, Switzerland

Corresponding author: Marcel G.A. van der Heijden, Institute for Sustainability Sciences, Agroscope, Reckenholzstrasse 191, CH-8046 Zurich, Switzerland, Tel.: +41 58468 72 78, Fax: +41 5846872 01, Email: marcel.vanderheijden@agroscope.admin.ch

luise.koehl@web.de 
Köhl et al.

\section{Abstract}

Arbuscular mycorrhizal (AM) fungi have been shown to play a crucial role in nutrient cycling and can reduce nutrient losses after rain induced leaching events. It is still unclear whether nutrient leaching losses vary depending on the AM fungal taxa that are present in soil. Using experimental microcosms with one of two different host plants (the grass Lolium multiflorum, or the legume Trifolium pratense) and inoculated with one of three different AM fungal species (Claroideoglomus claroideum, Rhizoglomus irregulare, and Funneliformis mosseae), we tested whether AM fungal species vary in their effects on nutrient leaching and plant productivity.

AM fungi reduced nitrogen leaching, and the effects varied depending on host plant species and the identity of the AM fungal species present in soil. The reduction of nitrogen leaching losses was strongest in microcosms planted with Trifolium. The effects of AM fungi on phosphorus leaching losses were relatively small, and in most cases not significant, although a significant negative correlation between root colonization and phosphate leaching was observed in microcosms planted with Lolium. AM fungi enhanced plant $\mathrm{P}$ uptake for both plant species, and different AM fungi varied in their effects on plant biomass and nutrient acquisition.

Our results demonstrate, for the first time, that AM fungal species differ in their effect on nutrient leaching. This indicates that agricultural practices that alter AM fungal communities also indirectly change nutrient cycling and nutrient leaching losses. 
Köhl et al.

\section{Keywords}

Arbuscular mycorrhizal fungi, nutrient leaching, nutrient uptake, phosphorus, nitrogen, sustainability, nutrient use efficiency, legume, grass 
Köhl et al.

\section{Introduction}

In many ecosystems substantial amounts of nutrients can be lost due to rain induced leaching events. Up to $160 \mathrm{~kg}$ of nitrogen $(\mathrm{N})$ and $30 \mathrm{~kg}$ of phosphorus $(\mathrm{P})$ per hectare can be leached annually (Sims et al., 1998; Herzog et al., 2008). Leaching losses pose environmental and economic problems because they contribute to the eutrophication of aquatic ecosystems (Carpenter et al., 1998). At the same time, nutrients lost from agro-ecosystems have to be replaced by the farmer with costly fertilizer, which also poses a problem due to the expected depletion of phosphorus deposits in the next 50-100 years (Cordell et al., 2009) and the high energy costs of $\mathrm{N}$ fertilizer production (Vance, 2001). The amount of nutrients lost varies widely and depends on factors such as climate, land use, soil type and vegetation type (Jung, 1972; Scholefield et al., 1993; Simmelsgaard, 1998; Di and Cameron, 2002). Recently it has been observed that soil biota such as arbuscular mycorrhizal (AM) fungi can reduce nutrient leaching losses and enhance nutrient retention in soil (Asghari et al., 2005; van der Heijden, 2010; Corkidi et al., 2011; Asghari and Cavagnaro, 2012; Verbruggen et al., 2012; Bender et al., 2015).

AM fungi are a group of soil fungi that form symbiotic associations with the majority of land plants (Smith and Read, 2008; van der Heijden et al., 2015). The fungus forms extensive hyphal networks in soil and forages efficiently for nutrients, primarily for $\mathrm{P}$, but also for $\mathrm{Zn}, \mathrm{N}$ and other nutrients that are delivered to their host plants in exchange for carbon (Smith and Read, 2008; Lehmann et al., 2013; Watts-Williams and Cavagnaro, 2014; Walder and van der Heijden, 2015). AM fungi have recently been reported to reduce nutrient leaching losses from soil (Asghari et al., 2005; van der Heijden, 2010; Asghari and Cavagnaro, 2012; Bender et al., 2015), but the underlying mechanisms are not fully understood (Cavagnaro et al., 2015). Exploration of a larger soil volume by extensive hyphal networks and efficient nutrient uptake and immobilization in plant and fungal biomass is considered one of the key mechanisms for the reduction of $\mathrm{P}$ and $\mathrm{N}$ leaching through AM fungi (Jakobsen et al., 1992; Cavagnaro et al., 2015). As AM fungi improve soil structure (Rillig and Mummey, 2006) and soil water retention (Augé, 2004), AM fungi could also impact the leachate volume. But evidence for this mechanism is weak, as not always an AM fungal mediated reduction in leaching volume was reported (Asghari et al., 2012). 
Köhl et al.

So far, only few studies investigated effects of AM fungi on nutrient leaching losses, and it is still unclear whether the reported effects are a general characteristic of the mycorrhizal symbiosis and are relevant under a wide range of conditions, or dependent on soil and ecosystem type, or host species. Moreover, while it is well established that different AM fungi have different effects on plant growth and nutrient uptake (Owusu-Bennoah and Mosse, 1979; Schenck and Smith, 1982; Jakobsen et al., 1992), it is still unclear whether different AM fungi also vary in their ability to influence nutrient leaching losses from soil. We expect that those AM fungal taxa that acquire large amounts of nutrients for their host plants or fungal taxa that form extensive hyphal networks and store nutrients in their mycelium are better able to reduce nutrient leaching losses compared to AM fungi that have marginal effects on plant nutrient uptake. In the later situation, nutrients are not biologically bound, freely available in soil and, thus, more prone to be lost due to rain or irrigation induced leaching events.

In this study we tested whether 1.) AM fungi can indeed reduce nutrient leaching losses from experimental grassland microcosms planted with two different host plant species, and 2.) whether AM fungal species vary in their effects on nutrient leaching. We investigated these questions using microcosms planted with a grass, Lolium multiflorum, or a legume, Trifolium pratense. The microcosms were inoculated with one of three different AM fungal species (Rhizoglomus irregulare (formerly known as Rhizophagus irregularis / Glomus intraradices), Funneliformis mosseae (formerly named Glomus mosseae) or Claroideoglomus claroideum (formerly known as Glomus claroideum)) or a nonmycorrhizal control inoculum. Effects on nutrient leaching were tested with a rain simulation after microcosms were fertilized. 
Köhl et al.

\section{Material and methods}

\subsection{Plant species, substrate and mycorrhizal inoculum}

In this study we present two similar experiments using different host plants, one with Lolium multiflorum Lam. cv. ORYX, Italian ryegrass, (experiment 1) and one with Trifolium pratense L. cv. Formica, red clover (experiment 2). We focused on both species as they are widespread in natural grasslands and are often the dominant plant species in pastures in Switzerland (Nyfeler, 2009; Suter et al., 2015). Moreover, both plant species represent different plant functional types (a grass and a nitrogen fixing legume) and respond differently to AM fungi. The grass, Lolium, is usually unresponsive to AM fungi (Wagg et al., 2011b; Köhl et al., 2014), whereas the legume Trifolium is highly mycotrophic (Köhl et al., 2014; Köhl et al., 2015). All seeds were surface sterilized with 5\% sodium hypochlorite for $5 \mathrm{~min}, 70 \%$ ethanol for 10 min and rinsed thoroughly with $\mathrm{dH}_{2} \mathrm{O}$. Plants were germinated on $1.5 \%$ sterile water agar.

Soil for the substrate originated from a permanent grassland at Research Station Agroscope in Zurich, Switzerland $\left(47^{\circ} 25^{\prime} 38.71^{\prime \prime} \mathrm{N}, 8^{\circ} 31^{\prime} 3.91^{\prime \prime}\right.$ E). The soil, a calcaric cambisol, was sieved through a 3 $\mathrm{mm}$ sieve, dried, and mixed with quartz sand at a ratio of $1: 1(\mathrm{v} / \mathrm{v})$. The mixture was gamma-sterilized using a dose of $30 \mathrm{kGy}$ and stored for two (experiment 1) or three months (experiment 2) at room temperature.

The sterilized substrate including the inoculum had a pH of 7.1 and contained $1.0 \%$ Humus, $8.7 \%$ clay, $6.3 \%$ silt and $84 \%$ sand. The substrate was phosphate poor with plant available $\mathrm{P}_{2} \mathrm{O}_{5}$ (extracted with $\mathrm{CO}_{2}$-saturated water) of $0.36 \mathrm{mg} / \mathrm{kg}$. Due to mineralization and nitrification processes during the storage and different inoculum substrates, mineral $\mathrm{N}$ content differed between the experiments. In experiment 1 the substrate initially contained $12.9 \mathrm{mg} \mathrm{NH}_{4}^{+} / \mathrm{kg}$ and $0.7 \mathrm{mg} \mathrm{NO}_{3}^{-} / \mathrm{kg}$, in experiment 2 it contained $4.9 \mathrm{mg} \mathrm{NH}_{4}{ }^{+} / \mathrm{kg}$ and $19.3 \mathrm{mg} \mathrm{NO}_{3}{ }^{-} / \mathrm{kg}$.

Experiment 1 (with Lolium as host plant) and experiment 2 (with Trifolium as host plant) consisted each of four treatments, plants were either inoculated with one of three AM fungi or received a nonmycorrhizal control treatment. Fungal species used were Claroideoglomus claroideum (N.C. Schenck \& G.S. Sm.) C. Walker \& A. Schüssler (formerly named Glomus claroideum), Rhizoglomus irregulare 
Köhl et al.

(Błaszk., Wubet, Renker \& Buscot) Sieverd., G.A. Silva \& Oehl (formerly known as Rhizophagus irregularis/ Glomus intraradices (Sieverding et al., 2014)), and Funneliformis mosseae (T.H. Nicolson \& Gerd.) C. Walker \& A. Schüssler (formerly known as Glomus mosseae). We applied isolate HG 181/ SAF4 of $C$. claroideum in experiment 1 and isolate HG 281a/ SAF6 in experiment 2, isolate SAF22 of $R$. irregulare (van der Heijden et al., 2006) in experiment 1 and isolate BEG75/ SAF16 (Jansa et al., 2002) in experiment 2, and isolate HG 505/ SAF10 of F. mosseae in both experiments.

All isolates are deposited in the Swiss Collection of Arbuscular Mycorrhizal Fungi (www.agroscope.ch/saf) and were propagated in the greenhouse on Zea mays L. (experiment 1) or Plantago lanceolata L. (experiment 2) in an autoclaved substrate made of $15 \%$ grassland soil and $85 \%$ hydrated lime or sand respectively. After four (experiment 1) and eight months (experiment 2) of growth, pots were left to dry out and the aboveground biomass was discarded. The roots were then cut into small pieces and mixed thoroughly with the rest of the substrate to serve as soil inoculum. Nonmycorrhizal controls were prepared analogously to the AM fungal inoculum. $R$. irregulare (=Ri), $F$. mosseae $(\mathrm{Fm})$ and C. claroideum $(\mathrm{Cc})$ colonized $95 \%, 62 \%$ and $16 \%$ of the root length of $Z$. mays and $81.5 \%, 33 \%$ and $21 \%$ of the root length of P. lanceolata. Both control inocula did not contain any AM fungal propagules.

\subsection{Experimental setup and artificial rain}

\subsubsection{Experiment 1: Effects of different AM fungal species on the grass Lolium multiflorum}

Lolium microcosms were established in PVC tubes with a diameter of $15.2 \mathrm{~cm}$ and a height of $40 \mathrm{~cm}$ (Figure S1 A). A total of $9.25 \mathrm{~kg}$ sterilized substrate including $11 \%(\mathrm{w} / \mathrm{w})$ thoroughly intermixed inoculum was added to each microcosm to a height of $35 \mathrm{~cm}$. The bottom of each microcosm consisted of a $500 \mu \mathrm{m}$ PP mesh, which permitted excess water to leach through. For better drainage a $3 \mathrm{~cm}$ layer of autoclaved sand was added to the bottom of the tubes. In each microcosm 33 Lolium seedlings were planted equally spaced apart.

Each microcosm received $77 \mathrm{ml}$ of a microbial wash to correct for differences in the non-mycorrhizal microbial communities between the inocula (Ames et al., 1987; Koide and Li, 1989). For this, $90 \mathrm{~g}$ of each inoculum including the non-mycorrhizal control, and $90 \mathrm{~g}$ of fresh field soil were mixed with 4.2 
Köhl et al.

$\mathrm{L} \mathrm{dH}_{2} \mathrm{O}$ and filtered through filter paper ( $\mathrm{N}^{\circ} 598$, Schleicher and Schuell, Dassel, Germany). All microcosms were arranged in a complete randomized block design with each of the four different treatments replicated ten times.

The plants were grown in a greenhouse with an average daily temperature of at least $24{ }^{\circ} \mathrm{C}$, a night temperature of at least $18{ }^{\circ} \mathrm{C}$ and 16 hours of light per day. Supplemental light was provided by $400 \mathrm{~W}$ high-pressure sodium lights when natural irradiation was lower than $300 \mathrm{~W}$. Plants were kept in the greenhouse for 20 weeks between March and August 2010. Lolium plants were watered with deionized water 3 times a week to $80 \%$ field capacity. Blocks were rotated randomly in the greenhouse when pots were watered. The microcosms were fertilized 11 weeks after planting with $100 \mathrm{ml}$ of a nutrient solution $\left(6 \mathrm{mM} \mathrm{KNO}_{3}, 4 \mathrm{mM} \mathrm{Ca} \mathrm{NO}_{3}\right) 2 * 4 \mathrm{H}_{2} \mathrm{O}, 2 \mathrm{mM} \mathrm{NH}_{4} \mathrm{H}_{2} \mathrm{PO}_{4}, 1 \mathrm{mM} \mathrm{MgSO}_{4} * 6 \mathrm{H}_{2} \mathrm{O}$ and micronutrients $(50 \mu \mathrm{M}$ $\mathrm{KCl}, 25 \mu \mathrm{M} \quad \mathrm{H}_{3} \mathrm{BO}_{3}, 2 \mu \mathrm{M} \quad \mathrm{MnSO}_{4} * 4 \mathrm{H}_{2} \mathrm{O}, 2 \mu \mathrm{M} \quad \mathrm{ZnSO}_{4} * 7 \mathrm{H}_{2} \mathrm{O}, \quad 0.5 \mu \mathrm{M} \quad \mathrm{CuSO}_{4} * 5 \mathrm{H}_{2} \mathrm{O}, \quad 0.5 \mu \mathrm{M}$ $\left.\left.\left(\mathrm{NH}_{4}\right) 6 \mathrm{Mo}_{7} \mathrm{O}_{24} * 4 \mathrm{H}_{2} \mathrm{O}, 20 \mu \mathrm{M} \mathrm{Fe}(\mathrm{Na}) \mathrm{EDTA}\right)\right)$ and 17 weeks after planting with $100 \mathrm{ml}$ of the same fertilizer reduced in $\mathrm{P}$ (same as before, but $0.5 \mathrm{mM} \mathrm{NH}_{4} \mathrm{H}_{2} \mathrm{PO}_{4}$ and $0.75\left(\mathrm{NH}_{4}\right)_{2} \mathrm{SO}_{4}$ instead of $2 \mathrm{mM}$ $\mathrm{NH}_{4} \mathrm{H}_{2} \mathrm{PO}_{4}$ ). This corresponded to a nutrient addition of $24.7 \mathrm{~kg} \mathrm{~N} / \mathrm{ha}$ and $4.3 \mathrm{~kg} \mathrm{P} / \mathrm{ha}$. Pest management was applied when necessary and according to Swiss regulations for organic farming (predatory mites Amblyseius swirskii against thrips and $\mathrm{Cu} / \mathrm{S}$ against powdery mildew, ladybugs against aphids).

The ability of different AM fungal species to reduce nutrient leaching was investigated after 20 weeks of plant growth using a rain simulator (Knacker et al., 2004). For this purpose, microcosms were

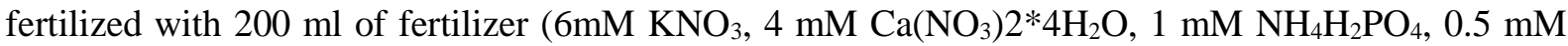
$\left(\mathrm{NH}_{4}\right)_{2} \mathrm{SO}_{4}, 1 \mathrm{mM} \mathrm{MgSO}{ }_{4} * 6 \mathrm{H}_{2} \mathrm{O}$ and micronutrients $\left(50 \mu \mathrm{M} \mathrm{KCl}, 25 \mu \mathrm{M} \mathrm{H}_{3} \mathrm{BO}_{3}, 2 \mu \mathrm{M} \mathrm{MnSO}{ }_{4} * 4 \mathrm{H}_{2} \mathrm{O}\right.$, $2 \mu \mathrm{M} \quad \mathrm{ZnSO}_{4} * 7 \mathrm{H}_{2} \mathrm{O}, \quad 0.5 \mu \mathrm{M} \quad \mathrm{CuSO}_{4} * 5 \mathrm{H}_{2} \mathrm{O}, 0.5 \mu \mathrm{M}\left(\mathrm{NH}_{4}\right)_{6} \mathrm{Mo}_{24} * 4 \mathrm{H}_{2} \mathrm{O}, 20 \mu \mathrm{M}$ Fe(Na)EDTA $\left.)\right)$ corresponding to $24.7 \mathrm{~kg} \mathrm{~N} / \mathrm{ha}$ and $3.4 \mathrm{~kg} \mathrm{P} / \mathrm{ha}$. After 48 hours, the microcosms were watered to $100 \%$ field capacity and exposed to $2 \mathrm{~L}$ artificial rain applied with the rain simulator following the same procedure as in Köhl et al. (2014). The leachate draining off the microcosms was collected, weighed and analyzed. The pots were harvested five hours after the raining started.

\subsubsection{Experiment 2: Effects of different AM fungal species on the legume Trifolium pratense}


Köhl et al.

The second experiment, using Trifolium pratense as a host plant, was performed in $3 \mathrm{~L}$ pots (upper $\varnothing$ $16 \mathrm{~cm}$, lower $\varnothing 12.5 \mathrm{~cm}$, height $19.3 \mathrm{~cm}$, Figure S1 B). Pots were modified to contain a polypropylene mesh $(500 \mu \mathrm{m})$ instead of a solid bottom, and $3 \mathrm{~cm}$ layer of an autoclaved sand-gravel was added to improve drainage. The sterilized substrate was thoroughly intermixed with $8.7 \%$ inoculum (w/w), and the resulting $3.5 \mathrm{~kg}$ soil mixture was used to fill each pot. $55 \mathrm{ml}$ of a microbial wash was added to each pot to equalize the non-mycorrhizal microbial community between treatments. To prepare this microbial wash, $40 \mathrm{~g}$ of each inoculum and $80 \mathrm{~g}$ of fresh grassland soil were suspended in $2.4 \mathrm{~L}$ of $\mathrm{dH}_{2} \mathrm{O}$ and filtered through a filter paper ( ${ }^{\circ} 598$, Schleicher and Schuell, Dassel, Germany) to exclude mycorrhizal propagules. In each microcosm 33 Trifolium seedlings were planted equally spaced apart.

All microcosms were arranged in a complete randomized block design in the greenhouse with each of the four different treatments replicated eight times. Greenhouse conditions, watering and pest management were regulated as described for the first experiment. Trifolium plants grew in the greenhouse for 21 weeks between May and September 2010. Trifolium received a lower amount of nutrients compared to Lolium because Trifolium fixes nitrogen and usually enhances $\mathrm{N}$ availability. In addition, it is recommended not to fertilize legume crops with nitrogen in Switzerland (Flisch et al., 2009). After 14 weeks of plant growth $10 \mathrm{ml}$ of a fertilizer with low $\mathrm{P}$ was added $\left(0.5 \mathrm{mM} \mathrm{KH}_{2} \mathrm{PO}_{4}, 1\right.$ $\mathrm{mM} \mathrm{MgSO}{ }_{4}$ and micronutrients $\left(50 \mu \mathrm{M} \mathrm{KCl}, 25 \mu \mathrm{M} \mathrm{H}_{3} \mathrm{BO}_{3}, 2 \mu \mathrm{M} \mathrm{MnSO}_{4} * 4 \mathrm{H}_{2} \mathrm{O}, 2 \mu \mathrm{M} \mathrm{ZnSO}{ }_{4} * 7 \mathrm{H}_{2} \mathrm{O}\right.$, $0.5 \mu \mathrm{M} \mathrm{CuSO}_{4} * 5 \mathrm{H}_{2} \mathrm{O}, 0.5 \mu \mathrm{M}\left(\mathrm{NH}_{4}\right)_{6} \mathrm{Mo}_{7} \mathrm{O}_{24} * 4 \mathrm{H}_{2} \mathrm{O}, 20 \mu \mathrm{M}$ Fe(Na)EDTA).

Analogously to experiment 1, leaching from Trifolium pots was determined after 21 weeks of plant growth using a rain simulator. In contrast to experiment $1,100 \mathrm{ml}$ of fertilizer $(2 \mathrm{mM} \mathrm{Ca}(\mathrm{NO} 3) 2 * 4 \mathrm{H} 2 \mathrm{O}$, $2 \mathrm{mM}$ NH4H2PO4, $1 \mathrm{mM} \mathrm{MgSO} 4 * 6 \mathrm{H} 2 \mathrm{O}, 3 \mathrm{mM} \mathrm{K} 2 \mathrm{SO} 4)$, corresponding to $4.8 \mathrm{~kg} \mathrm{~N} /$ ha and $3.5 \mathrm{~kg}$ $\mathrm{P} / \mathrm{ha}$, were added to each pot 48 hours before raining. Each pot received a simulated rain of $925 \mathrm{ml}$ (equal to $100 \%$ field capacity). The leachate was collected for three hours and subsequently weighed before pots were harvested.

\subsection{Harvest and analyses}

After 9 weeks for experiment 1 and 7 weeks for experiment 2 shoots were cut $5 \mathrm{~cm}$ aboveground to simulate hay making or grazing. Because of low plant growth in the Trifolium control treatment of 
Köhl et al.

experiment 2 , the intermediate harvest was not done. After the simulated rain at the final harvest (20 and 21 weeks respectively for experiment 1 and 2), shoots were cut at the soil surface. Shoots were dried at $60^{\circ} \mathrm{C}$ for 48 hours and weighed. Microcosms were emptied and larger roots were collected, washed and weighed. In order to obtain the remaining fine roots, the soil substrate was homogenized and a weighed soil sample was taken and washed by repeatedly decanting the watered subsamples onto a 250 $\mu \mathrm{m}$ mesh. Weighed subsamples of both root samples were dried at $60^{\circ} \mathrm{C}$ for 48 hours and total root biomass per microcosm was calculated. Subsamples of both root samples were cut into pieces $<1 \mathrm{~cm}$, mixed in water and stored in 50\% ethanol for mycorrhizal root colonization analysis. In addition to this, soil samples were collected for nutrient and microbial biomass analysis (stored at $4^{\circ} \mathrm{C}$ ) and mineral $\mathrm{N}$ analysis (stored at $-20^{\circ} \mathrm{C}$ ). Soil water content was determined gravimetrically to standardize the results for all microcosms.

\subsection{Analyses}

\subsubsection{Microbial parameters}

Mycorrhizal root colonization was determined using the ink-vinegar method described by Vierheilig et al. (1998). For this purpose, roots were cleared with $10 \% \mathrm{KOH}$ and stained with $5 \%$ ink-vinegar. Percentage of root length colonized and frequency of hyphae, arbuscules and vesicles was quantified microscopically at a magnification of 200x with the intersect method (McGonigle et al., 1990) using 100 intersections. Soil microbial biomass was estimated by chloroform-fumigation-extraction (CFE) according to Vance et al. (1987). CFE was done in duplicates with $20 \mathrm{~g}$ (dry matter) fresh subsamples that were extracted with $80 \mathrm{ml}$ of a $0.5 \mathrm{M} \mathrm{K}_{2} \mathrm{SO}_{4}$. Organic C (TOC) was quantified using infrared spectrometry after combustion at $850^{\circ} \mathrm{C}$ (DIMATOC ${ }^{\circledR} 2000$, Dimatec, Essen, Germany). Using the same sample, total microbial $\mathrm{N}$ was subsequently determined by chemoluminescence $\left(\mathrm{TN}_{\mathrm{b}}\right.$, Dimatec, Essen, Germany). Soil microbial biomass C was then calculated according to Joergensen (1996) and microbial N according to Joergensen and Mueller (1996).

\subsubsection{Plant nutrient analysis}

Shoots were pooled across the two harvests for each species. Shoots and roots were ground for nutrient analysis. Total shoot nitrogen concentration was determined using a CHNSO analyzer (Euro EA, 
Köhl et al.

HEKAtech $\mathrm{GmbH}$, Wegberg, Germany). For plant $\mathrm{P}$ determination, ground biomass was ashed at $600^{\circ} \mathrm{C}$ and digested using $6 \mathrm{M} \mathrm{HCl}$. Digests were diluted and $\mathrm{P}$ was quantified colorimetrically according to the molybdenum blue method (Watanabe and Olsen, 1965).

\subsubsection{Leachate analysis}

The collected leachates were very clear and were not filtered before analysis. Leached phosphate and nitrate were quantified using a Dionex DX500 anion chromatograph (Dionex Corporation, Sunnyvale, CA) with an IonPac AG4A-SC guard column, an IonPac AS4A-SC analytical column (both 4mm) and $1.8 \mathrm{mM} \mathrm{Na} 2 \mathrm{CO} 3 / 1.7 \mathrm{mM} \mathrm{NaHCO} 3$ as eluent. Ammonium was determined spectrophotometrically using the Berthelot reaction method (Krom, 1980). The absorption of the resulting coloured complexes was quantified with the continuous flow analyzer SAN++ (Skalar Analytical B.V., Breda, Netherlands). The total amount of dissolved $\mathrm{P}$ was determined colorimetrically according to the molybdenum blue ascorbic acid method (Watanabe and Olsen, 1965) after oxidation with Oxisolv® (Merck, Darmstadt, Germany). The difference between total dissolved $\mathrm{P}$ and phosphate was defined as unreactive $\mathrm{P}$. This fraction comprises all compounds not directly available to plants such as soluble and particulate organic $\mathrm{P}$ compounds, polyphosphates and particulate inorganic material like clays (Daniel and DeLaune, 2009). As leached volumes differed between treatments, leached nutrients are presented as total amount leached. To calculate this, the volume of the leachate was multiplied with the particular nutrient concentration.

\subsubsection{Soil analyses}

All soil analyses were conducted by Agroscope, Institute for Sustainability Sciences, Zurich, Switzerland according to the Swiss reference methods for soil analyses (Forschungsanstalt Agroscope Reckenholz-Tänikon ART and Forschungsanstalt Agroscope Changins-Wädenswil ACW, 1996). Plant available soil $\mathrm{P}$ was quantified colorimetrically analogously to the total $\mathrm{P}$ in the leachate after extraction with $\mathrm{CO}_{2}$ saturated water $(6 \mathrm{mMol} \mathrm{CO} 2$ per $75 \mathrm{ml})$. Soil $\mathrm{NO}_{3}^{-}$and $\mathrm{NH}_{4}^{+}$were determined colorimetrically after extraction with $0.01 \mathrm{M} \mathrm{CaCl} 2 . \mathrm{No} \mathrm{NO}_{3}{ }^{-}$was detected at the end of the experiments (except for the Trifolium control). Total nitrogen was assessed by first reducing nitrate and organic $\mathrm{N}$ to $\mathrm{NH}_{4}{ }^{+}$, followed by quantifying the $\mathrm{NH}_{4}{ }^{+}$by distillation and titration. 
Köhl et al.

\subsection{Statistical analysis}

Statistical analyses were conducted using the software R version 3.0.1 (R Core Team, 2013). Experiment 1 (Lolium) and experiment 2 (Trifolium) were analyzed separately, as the two experiments cannot be compared directly (e.g. the soil volume and fertilization varied between the two experiments and different fungal isolates were used in experiment 1 and 2). In order to assess whether the nonmycorrhizal control differed from the three treatments with fungal inoculation, a contrast was created separating the control from the mycorrhizal treatments. The contrast and the inoculum identity (4 levels) as well as the block as error term were used as factors in an ANOVA to analyze all response variables. A t-test or a Wilcoxon rank sum test (when errors were non-normal) was subsequently performed to specifically test whether the control treatment differed from the individual mycorrhizal treatments. The effect of the fungal identity was tested with an ANOVA analysis with block and inoculum identity as factors while excluding the control treatment from the data set. A Tukey HSD test was performed to specifically test which treatments differed from each other. Correlations between two variables were assessed using Pearson's correlation. In the text, all figures and tables presented show estimates of the means with their standard error (SEM). There was one missing value in root biomass as well as root $\mathrm{N}$ content (F. mosseae, experiment 1$)$. 
Köhl et al.

\section{Results}

\subsection{Mycorrhizal colonization and microbial biomass}

All mycorrhizal isolates successfully colonized Lolium and Trifolium roots and each of the isolates formed arbuscules and vesicles, structures specific for AM fungi. The non-mycorrhizal control treatments remained largely uncolonized (total root colonization $<1 \%$ ) in both experiments showing that we successfully eliminated AM fungi. Interestingly, mycorrhizal isolates differed in their colonization rate of Trifolium and Lolium roots (Lolium: $\mathrm{F}_{2,23}=1075.18, \mathrm{p}<0.001$, Trifolium: $\mathrm{F}_{2,18}=160.20, \mathrm{p}<0.001$, Figure 1). The highest colonization was observed in roots inoculated with $\mathrm{Ri}$ (= Rhizoglomus irregulare), ranging from 84 to $99 \%$. Ri also produced significantly more vesicles and arbuscules than the other two fungi (Figure 1). Colonization performance of Fm (= Funneliformis mosseae) and Cc (=Claroideoglomus claroideum) was host plant dependent, as Fm colonized Trifolium roots to a greater extent than Cc (Fm 58-74\%, Cc 31-53\%), whereas in Lolium roots a greater colonization by Cc (30$39 \%)$ compared to Fm (5-25\%) was observed (Figure 1).

The microbial biomass $\mathrm{C}$ and $\mathrm{N}$ did not change due to mycorrhizal inoculation in Lolium microcosms (C: $\mathrm{F}_{1,32}=0.54, \mathrm{p}=0.47$, Figure 1), but significantly increased by $99 \%(\mathrm{C})$ and $177 \%(\mathrm{~N})$ respectively upon addition of AM fungi, compared to the non-mycorrhizal control in Trifolium pots (C: $\mathrm{F}_{1,25}=126.27$, $\left.\mathrm{p}<0.001, \mathrm{~N}: \mathrm{F}_{1,25}=156.45, \mathrm{p}<0.001\right)$. Microbial biomass $\mathrm{C}$ and $\mathrm{N}$ was significantly influenced by fungal identity (Lolium C: $\mathrm{F}_{2,23}=53.53$, $\mathrm{p}<0.001$, Trifolium $\mathrm{C}: \mathrm{F}_{2,18}=19.33$, $\mathrm{p}<0.001$, Table $\mathrm{S} 1$ ).

\subsection{Biomass production}

The biomass of the highly mycotrophic Trifolium increased significantly by $1228.4 \%$ in response to AM colonization $\left(\mathrm{F}_{1,25}=3091.20, \mathrm{p}<0.001\right.$, Figure 2$)$. In contrast, the biomass of Lolium was not affected by AM fungal inoculation $\left(\mathrm{F}_{1,32}=2.84, \mathrm{p}=0,10\right.$, Figure 2). Effects on biomass for both host plants were dependent on the AM fungal species present. Similar to the effect on root colonization, Ri increased Trifolium biomass more than the other two isolates, while Lolium growth was actually decreased relative to the non-mycorrhizal control by Ri inoculation. Interestingly, percentage of root length colonized by AM fungi correlated to an extent with the total biomass produced: The higher the colonization level of 
Köhl et al.

Trifolium roots the more biomass was gained $(\mathrm{r}=0.7, \mathrm{p}<0.001)$ and vice versa for Lolium plants $(\mathrm{r}=-0.68$, $\mathrm{p}<0.001)$

\subsection{Nutrient uptake}

Colonization by AM fungi significantly increased $\mathrm{P}$ and $\mathrm{N}$ content of Trifolium ( $\mathrm{P}: \mathrm{F}_{1,25}=3374.66$, $\mathrm{p}<0.001, \mathrm{~N} \mathrm{~F}_{1,25}=1566.97, \mathrm{p}<0.001$, Figure 3). Moreover, the three different AM fungal isolates differed in their effects on Trifolium $\mathrm{N}$ and $\mathrm{P}$ content $\left(\mathrm{P}: \mathrm{F}_{2,18}=42.65, \mathrm{p}<0.001, \mathrm{~N}: \mathrm{F}_{2,18}=36.24, \mathrm{p}<0.001\right) . \mathrm{P}$ and $\mathrm{N}$ content of microcosms inoculated with Fm were lower compared to plants inoculated with Ri and $\mathrm{Cc}$ indicating that Fm was less effective in nutrient uptake than the other two isolates.

The P content of Lolium plants inoculated with each of the three AM fungal isolates was significantly higher than in the non-mycorrhizal control plants $\left(\mathrm{F}_{1,32}=40.44, \mathrm{p}<0.001\right.$, Figure 3$)$. Interestingly, even though Lolium plants grown in microcosms inoculated with Ri had the lowest biomass, they did not contain lower amounts of $\mathrm{P}$ compared to the other isolates. Lolium $\mathrm{N}$ shoot content was decreased by mycorrhizal inoculation $\left(\mathrm{F}_{1,32}=5.72, \mathrm{p}=0.023\right)$ and the extent of the effect was dependent on the fungal species $\left(\mathrm{F}_{2,23}=5.38, \mathrm{p}=0.012\right)$. Lolium root $\mathrm{N}$ content was affected neither by inoculation $\left(\mathrm{F}_{1,32}=0.01\right.$, $\mathrm{p}=0.93)$ nor by fungal identity $\left(\mathrm{F}_{2,22}=2.67, \mathrm{p}=0.09\right.$, Table $\left.\mathrm{S} 1\right)$.

\subsection{Nutrient leaching}

\subsubsection{Phosphorus}

Phosphorus leaching was not affected by inoculation with mycorrhizal fungi with no significant

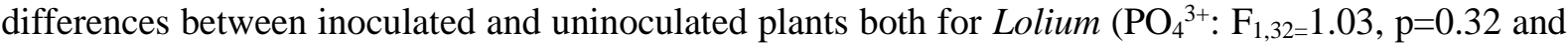
unreactive $\left.\mathrm{P}: \mathrm{F}_{1,32}=0.29, \mathrm{p}=0.59\right)$ and Trifolium $\left(\mathrm{PO}_{4}{ }^{3-}: \mathrm{F}_{1,25}=1.29, \mathrm{p}=0.27\right.$, Figure 4). An exception was the leaching of unreactive $\mathrm{P}$ in Trifolium microcosms which was significantly increased in the mycorrhizal treatments compared to the non-mycorrhizal control $\left(\mathrm{F}_{1,25=} 21.55\right.$, $\mathrm{p}<0.001$, Figure 4). Comparing each fungal strain individually with the control, $\mathrm{Cc}$ reduced the unreactive $\mathrm{P}$ fraction in the leachate of Lolium microcosms by $13 \%\left(\mathrm{t}_{18}=2.50, \mathrm{p}=0.022\right.$, Table 1$)$, whereas Fm increased $\mathrm{PO}_{4}{ }^{3-}$ : leaching by $46 \%$ ( $\left.\mathrm{t}_{18}=-2.74, \mathrm{p}=0.013\right)$. The identity of the fungus used for inoculation determined the amounts of nutrients leached (Lolium $\mathrm{PO}_{4}{ }^{3-}: \mathrm{F}_{2,23}=14.51, \mathrm{p}=\mathrm{p}<0.001$ and unreactive $\mathrm{P}: \mathrm{F}_{2,23}=8.01$, $\mathrm{p}=0.002$, Trifolium unreactive $\mathrm{P}: \mathrm{F}_{2,18}=11.39, \mathrm{p}<0.001$, Table $\mathrm{S} 1$ ) except for $\mathrm{PO}_{4}{ }^{3-}$ leached from 
Köhl et al.

Trifolium microcosms $\left(\mathrm{F}_{2,18}=0.16, \mathrm{p}=0.86\right)$. Phosphate leaching from Lolium microcosms was positively correlated with total biomass production $(\mathrm{r}=0.5, \mathrm{p}=0.005$, Table $\mathrm{S} 2)$ and negatively with mycorrhizal colonization level ( $\mathrm{r}=-0.65, \mathrm{p}<0.001$, Figure S3). Increasing microbial carbon also enhanced phosphate leaching from Lolium pots as well $(\mathrm{r}=0.56, \mathrm{p}=0.001)$. In contrast, Trifolium biomass production correlated negatively with the amount of unreactive $\mathrm{P}$ leached $(\mathrm{r}=-0.53, \mathrm{p}=0.008$, Table S2), as well as Trifolium $\mathrm{P}$ content $(\mathrm{r}=-0.64, \mathrm{p}<0.001$, Figure $\mathrm{S} 4)$.

\subsubsection{Nitrogen}

Lolium and Trifolium microcosms differed in their effects on nitrogen leaching from microcosm due to the mycotrophic and N-fixing nature of Trifolium (Figure 4, Figure S2). Nitrogen leaching from Trifolium pots was highly affected by mycorrhizal inoculation. Ammonium losses were 3.3 times higher in the presence of $\mathrm{AM}$ fungi, whereas $\mathrm{NO}_{3}{ }^{-}$losses were 22 times lower in mycorrhizal treatments compared to the control. In Trifolium microcosms the fungal identity did not affect nitrogen leaching

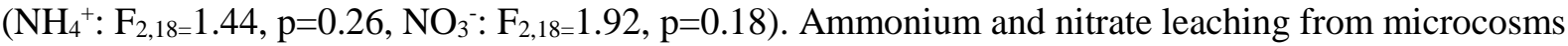
planted with Lolium were, in contrast to Trifolium, not affected by mycorrhizal inoculation in general $\left(\mathrm{NH}_{4}{ }^{+}: \mathrm{F}_{1,32}=3.41, \mathrm{p}=0.07, \mathrm{NO}_{3}{ }^{-}: \mathrm{F}_{1,32}=0.51, \mathrm{p}=0.48\right)$, but $\mathrm{NH}_{4}{ }^{+}$and $\mathrm{NO}_{3}{ }^{-}$losses were influenced by fungal identity and reduced in microcosms with $\mathrm{Cc}\left(\mathrm{NH}_{4}^{+}: \mathrm{t}_{18}=2.75, \mathrm{p}=0.013\right)$ and $\mathrm{Ri}\left(\mathrm{NH}_{4}^{+}: \mathrm{W}=22\right.$, $\mathrm{p}=0.04, \mathrm{NO}_{3}-\mathrm{W}=13, \mathrm{p}=0.005$, Table 1 ) compared to the non-mycorrhizal control. Fungal identity only affected ammonium leaching $\left(\mathrm{F}_{2,23}=13.68, \mathrm{p}<0.001\right)$ with $\mathrm{Cc}$ and $\mathrm{Ri}$ having the highest reduction in ammonium losses.

Neither plant biomass, nor root colonization or plant nutrient uptake could explain differences in leaching effects between mycorrhizal species (Table S2, analyses without control treatment). Only the total root length colonized by AM fungi in inoculated Trifolium plants correlated positively with the total amount of $\mathrm{NH}_{4}{ }^{+}$leached $(\mathrm{r}=0.41, \mathrm{p}=0.045)$. The remaining mineral nitrogen in the soil at the end of the experiment reflected the amount of nitrogen that was leached (Table S3): The more nitrogen leached the more $\mathrm{N}$ was available in the soil at the end of the experiment. Exceptions were the $\mathrm{NH}_{4}^{+}$ level in the Trifolium control treatment as well as $\mathrm{NO}_{3}{ }^{-}$in the soil of $\mathrm{Gc}$ and $\mathrm{Ri}$ inoculated Lolium 
Köhl et al.

microcosms. Here, the amount of $\mathrm{N}$ in the soil was comparable to the other treatments and much higher than the amount of $\mathrm{N}$ leached (Table S3). 
Köhl et al.

\section{Discussion}

The positive effects of AM fungi on plant growth and nutrition are well known. However, the effects of AM fungi on other ecosystem functions, such as effects on nutrient retention in soils are less well explored (for review see Cavagnaro et al., 2015). This study, together with other recent studies (Asghari and Cavagnaro, 2012; Bender et al., 2015; Bender and van der Heijden, 2015) demonstrates that AM fungi can reduce $\mathrm{N}$ losses from soil, sometimes resulting in a substantial reduction of nitrogen leaching. Other studies showed that the effects of AM fungi on nutrient leaching depend on host plant species (van der Heijden, 2010; Corkidi et al., 2011) and soil type (Bender et al., 2015). This study, using two different host plants and three different AM fungal species, partly confirms these results and puts the leaching effects in a more context dependent perspective. It shows, for the first time, that nutrient leaching is also influenced by the identity of the AM fungal species colonizing the roots and on the host plant/ AM fungal species combination.

\subsection{AM fungi affect nutrient leaching}

In Trifolium microcosms, a reduction in total leached nitrogen of $60.53 \mathrm{~kg} / \mathrm{ha}$ was achieved by AM fungal inoculation compared to the non-mycorrhizal control. In Lolium microcosms the reduction was very low with $0.18 \mathrm{~kg} \mathrm{~N} / \mathrm{ha}$. We assume that differences in the growth response of Lolium and Trifolium explained effects of AM fungi on nitrogen leaching losses. Trifolium was highly dependent on the presence of AM fungi, and nitrogen uptake by $\mathrm{AM}$ fungi and plant roots and its subsequent immobilization in fungal and plant biomass is probably the main mechanism for a reduction of nitrogen leaching losses by AM fungi in association with Trifolium. In contrast, AM fungi had a minor effect on Lolium biomass and did not influence the plant $\mathrm{N}$ content of Lolium, probably explaining why effects on nitrogen leaching losses were relatively small for this plant species. Similarly, Asghari et al. (2012) showed greater biomass production and 40 times less $\mathrm{N}$ lost to leaching in mycorrhizal tomato plants compared to non-mycorrhizal mutants. In contrast, van der Heijden (2010) could not detect any effect of G. irregulare on nitrate leaching in a grassland similar to the system we used, with grass species having the same biomass with and without AM fungi. 
Köhl et al.

We did not find any overall differences in P leaching between the mycorrhizal treatments and the nonmycorrhizal control in Lolium and Trifolium microcosms (only unreactive P was increased in clover pots with AM fungi present; Figure 4). The absence of an effect on total P leaching is surprising, as significantly more $\mathrm{P}$ was transferred to the plant biomass in mycorrhizal treatments, even in Lolium plants. Furthermore, the microbial biomass $\mathrm{C}$ in Trifolium microcosms was higher in the mycorrhizal treatments indicating a higher microbial P storage as well. The removal of $\mathrm{P}$ into Trifolium subterraneum and fungal biomass was shown by Asghari et al. (2005) to be one reason for a reduced P leaching in AM fungi presence. The substrate used in this study was very sandy (84\%) and thus should favor higher P leaching losses (Weaver et al., 1988; Atalay, 2001). We assume that the soil substrate used in this study, a calcaric cambisol, has a strong P-fixing ability, and thus very small amounts of $\mathrm{P}$ were found in the leachate. Bender et al. (2015) used a similar substrate based on the same pasture soil and observed only minor P leaching losses compared to a heath soil, confirming our results. Phosphate is usually immobile and strongly fixed to soil particles or immobilized when complexes with iron, aluminum or calcium are being formed, and as a consequence phosphorus leaching losses are usually low. In contrast nitrate is much more mobile in soil and, therefore, prone to leaching (Havlin et al.,2005).

General conclusions about the effects of AM fungi on nutrient leaching losses should be carefully formulated. A close examination of the reported benefits of AM fungi by a number of studies suggests that these could be largely dependent on biotic and abiotic factors of the experiment. Differences in host plant identity, soil type, fertilization treatment, inoculum identity and soil nitrogen and phosphorus pools and availability could explain why results vary so strongly across studies. While this does not challenge the validity of previous findings, future studies need to focus on examining the precise mechanisms that influence leaching effects of AM fungi. Moreover, AM fungi also influence two other sources of $\mathrm{N}$ loss, namely leaching of dissolved organic nitrogen and the loss of $\mathrm{N}_{2}$ and $\mathrm{N}_{2} \mathrm{O}$ through denitrification (Bender et al., 2014; Bender et al., 2015). In most studies, including this one, these factors were not investigated.

\subsection{AM fungal species dependent effect on ecosystem services}

Earlier work showed that different AM fungal taxa differentially influenced plant biomass and nutrient uptake (Ravnskov and Jakobsen, 1995; Taylor and Harrier, 2000; Hart and Reader, 2002; Jansa et al., 
Köhl et al.

2005). This study confirms that different AM fungal taxa vary in their effects on plant biomass production and $\mathrm{P}$ content. The results show that these effects were, at least in part, explained by species specific differences in root colonization. The AM fungus with the highest levels of root colonization (Ri) had the strongest effects on plant biomass (resulting in the greatest growth stimulation $(+1170 \%)$ for the mycotrophic plant species (Trifolium) and the greatest growth suppression (-18\%) for the grass species (Lolium)).

While earlier work focused on the effects of different AM fungi on plant biomass and nutrient uptake, it was still unclear whether different AM fungi could also influence nutrient leaching losses. Here, we demonstrate, for the first time, that different AM fungi can vary in their effect on nutrient leaching. It confirms a correlative study by Verbruggen et al. (2012) who demonstrated that the abundance of specific AM fungal taxa, as determined by terminal-RFLP, correlated well with plant productivity and $\mathrm{PO}_{4}{ }^{3-}$ leaching from microcosms. The present study, together with the one by Verbruggen et al. (2012), thus indicates that the composition of the AM fungal community can influence nutrient leaching losses from soil.

The precise mechanisms by which AM fungi reduce nutrient leaching are unclear (Cavagnaro et al., 2015). Effects of AM fungi on plant nutrient uptake could, in part, be related to their effects on nutrient leaching losses. Ri developed the highest root colonization level among the three AM fungal species and plants inoculated with Ri took up the largest amount of P. At the same time, Ri microcosms planted with Lolium leached the least amount of P (negative correlation between root length colonized and phosphate leaching, Figure S3). However, such an effect was not found for Trifolium indicating that other factors must be involved as well.

It has been observed that AM fungi alter root and hyphae associated bacterial communities involved in N (Amora-Lazcano et al., 1998; Veresoglou et al., 2012; Bender et al., 2014) and P cycling (Kim et al., 1998; Villegas and Fortin, 2001, 2002). Such changes in microbial communities may influence nutrient leaching losses. Moreover, AM fungi exude nutrient binding glycoproteins (Rillig and Mummey, 2006), and these may also play an additional role in explaining differences in nutrient losses from soil cores. Mycorrhizal impact on soil structure and soil water retention can provide further explanation for altered 
Köhl et al.

nutrient losses in presence of AM fungi (Augé, 2004; Rillig and Mummey, 2006), although an AMmediated reduction in nutrient leaching was not always shown (Asghari et al., 2012; Figure S6).

\subsection{Effects on host plants}

Two different host plants were chosen for their agronomic importance and their different responses to AM fungi. L. multiflorum, like many grasses, is colonized by AM fungi, but its biomass does not respond strongly to AM fungi (Wagg et al., 2011a; Bender et al., 2014; Köhl et al., 2014). By using an unresponsive grass, we intended to uncover the proportion of the mycorrhizal effect on nutrient leaching that is not related to increased nutrient storage in the plant biomass.

In contrast, the legume $T$. pratense is highly mycotrophic, and it usually benefits greatly in terms of biomass production and plant nutrient content from mycorrhizal infection (Wagg et al., 2011a; Köhl et al., 2014; Köhl et al., 2015). As a consequence, the soil nutrient concentrations in pots with Trifolium also differed between mycorrhizal and non-mycorrhizal treatments at the end of the experiment, and it is therefore much more difficult to separate effects of AM fungi on plant growth from those on nutrient leaching.

The most evident difference in nutrient leaching between Lolium and Trifolium microcosms was the amount of nitrate leached. With both hosts, nitrate leaching was reduced by AM fungal inoculation compared to the non-mycorrhizal control (Figure 4). But comparing the two plant systems, $\mathrm{NO}_{3}{ }^{-}$ amounts leached per ha were 292 times higher in the Trifolium control compared to the Lolium control $(0.21 \mathrm{~kg} / \mathrm{ha}$ vs. $62.31 \mathrm{~kg} \mathrm{~N} / \mathrm{ha})$ and 14 times higher when AM fungi were present $(0.12 \mathrm{~kg} / \mathrm{ha}$ vs. 1.65 $\mathrm{kg} / \mathrm{ha}$ ). This observation is consistent with other studies reporting that clover abundance is positively correlated with N leaching (Loiseau et al., 2001; Scherer-Lorenzen et al., 2003; Bouman et al., 2010). Grass systems usually have a high $\mathrm{N}$ efficiency and thus lower nitrogen losses via leaching (Simmelsgaard, 1998). Scherer-Lorenzen et al. (2003) detected only very low rates of N leaching in pure grass monocultures and mixtures $\left(<1 \mathrm{~kg} \mathrm{NO}_{3}-\mathrm{N} \mathrm{ha}^{-1 *} \mathrm{yr}^{-1}\right)$, whereas low diversity grasslands containing Trifolium had equally high $\mathrm{N}$ losses as bare ground plots $\left(100 \mathrm{~kg} \mathrm{NO}_{3}-\mathrm{N} \mathrm{ha}^{-1 *} \mathrm{yr}^{-1}\right)$. The higher $\mathrm{N}$ leaching from Trifolium microcosms, despite the lower N fertilization (Lolium $29.4 \mathrm{~kg} \mathrm{~N} /$ ha, Trifolium $4.8 \mathrm{~kg} / \mathrm{ha}$ ) can be attributed to low Trifolium biomass in microcosms without AM fungi (see above) and 
Köhl et al.

the symbiotic $\mathrm{N}$-fixing activity of the legume. The nitrogen fixation can range from $50-250 \mathrm{~kg} \mathrm{~N} \mathrm{ha}$

$1 * \mathrm{yr}^{-1}$ (Ledgard and Giller, 1995), which would exceed the amount of $\mathrm{N}$ fertilized in grass microcosms. The high $\mathrm{N}$ availability in Trifolium microcosms was also shown by the high plant N:P ratio (>16), which indicates that the plants were P limited, especially in the control treatment (Koerselman and Meuleman, 1996) (Figure S5). In contrast, Lolium growth was N limited in all treatments (N:P ratio < 14). As all microcosms received an AM fungi free filtrate of fresh grassland soil, we assume that $\mathrm{N}$ fixing, decomposing, denitrifying and nitrifying microbes were equally present in all treatments, although AM fungi will have a certain impact on the microbial background (Marschner and Baumann, 2003). Furthermore, the experimental soil at the start of the experiment contained more nitrate in the Trifolium experiment than in the Lolium experiment. This difference disappeared by the end of the greenhouse trials.

\section{Conclusion}

Here, we demonstrate that AM fungi not only influence plant growth and nutrient uptake but also ecosystem services such as nutrient retention. We demonstrate, for the first time, that AM fungal species differ in their effect on nutrient leaching. In view of the urgent need for a more sustainable, low-input agriculture, these properties of AM fungi might be utilized to reduce fertilizer input and environmental pollution through fertilizer runoff. As different AM fungal species differ in the quantity and quality of ecosystem services they provide (Ravnskov and Jakobsen, 1995; Smith et al., 2000), it has to be considered that the AM fungal community structure in an ecosystem will be of importance for its functioning. The AM fungal community can be intentionally manipulated by different agricultural management systems like fertilization, tillage practices and crop rotation (Douds Jr and Millner, 1999; Köhl et al., 2014; Säle et al., 2015). Field inoculation can systematically introduce powerful strains (like the Rhizoglomus irregulare in this study) (Köhl et al., 2015) to reduce nutrient losses from the field while decreasing the fertilizer input. Here, we have shown that the outcome of the mycorrhizal symbiosis is host plant dependent. Furthermore, nutrient leaching is highly dependent on soil type (Bender et al., 2015). Thus, more studies, especially under field conditions with various host plants, have to be conducted to reveal the practical relevance of AM fungi and their community structure for the prevention of nutrient losses. In our study, we have shown that the mechanisms underlying the mycorrhizal effects 
Köhl et al.

on nutrient leaching are diverse and not fully explained. As nutrient availability in the soil strongly depends on microbial activity, more emphasis should be placed on untangling the interdependent relationship between mycorrhiza and soil microbes and on how AM fungi shape the soil microbial community.

\section{Acknowledgements}

This work has been sponsored by grant 125428 of the Swiss National Science Foundation (SNSF) awarded to MvdH. We thank Beat Boller for the provision of seeds, Hans Jörg Bachmann, Hansruedi Bosshard, Brigitte Weiss and Erika Hinnen for help with plant nutrient analysis and Hans-Ruedi Oberholzer and Andrea Bonvicini for support with microbial biomass measurements. Special thanks to Kyle Hartman and two unknown reviewers for valuable comments on the manuscript.

Appendix A. Supplementary data 
Köhl et al.

\section{References}

Ames, R.N., Mihara, K.L., Bethlenfalvay, G.J., 1987. The establishment of microorganisms in vesiculararbuscular mycorrhizal and control treatments. Biology and Fertility of Soils 3, 217-223.

Amora-Lazcano, E., Vázquez, M.M., Azcón, R., 1998. Response of nitrogen-transforming microorganisms to arbuscular mycorrhizal fungi. Biology and Fertility of Soils 27, 65-70.

Asghari, H.R., Cavagnaro, T.R., 2012. Arbuscular mycorrhizas reduce nitrogen loss via leaching. PLoS ONE 7, e29825.

Asghari, H.R., Chittleborough, D.J., Smith, F.A., Smith, S.E., 2005. Influence of arbuscular mycorrhizal (AM) symbiosis on phosphorus leaching through soil cores. Plant and Soil 275, 181-193.

Atalay, A., 2001. Variation in phosphorus sorption with soil particle size. Soil and Sediment Contamination 10, 317-335.

Augé, R.M., 2004. Arbuscular mycorrhizae and soil/plant water relations. Canadian Journal of Soil Science 84, 373-381.

Bender, S.F., Conen, F., van der Heijden, M.G.A., 2015. Mycorrhizal effects on nutrient cycling, nutrient leaching and $\mathrm{N}_{2} \mathrm{O}$ production in experimental grassland. Soil Biology and Biochemistry 80, 283-292.

Bender, S.F., Plantenga, F., Neftel, A., Jocher, M., Oberholzer, H.-R., Köhl, L., Giles, M., Daniell, T.J., van der Heijden, M.G.A., 2014. Symbiotic relationships between soil fungi and plants reduce $\mathrm{N}_{2} \mathrm{O}$ emissions from soil. ISME Journal 8, 1336-1345.

Bender, S.F., van der Heijden, M.G.A., 2015. Soil biota enhance agricultural sustainability by improving crop yield, nutrient uptake and reducing nitrogen leaching losses. Journal of Applied Ecology 52, 228239. 
Köhl et al.

Bouman, O.T., Mazzocca, M.A., Conrad, C., 2010. Soil $\mathrm{NO}_{3}$-leaching during growth of three grasswhite-clover mixtures with mineral N applications. Agriculture Ecosystems and Environment 136, 111115.

Carpenter, S.R., Caraco, N.F., Correll, D.L., Howarth, R.W., Sharpley, A.N., Smith, V.H., 1998. Nonpoint pollution of surface waters with phosphorus and nitrogen. Ecological Applications 8, 559568.

Cavagnaro, T.R., Bender, S.F., Asghari, H.R., van der Heijden, M.G.A., 2015. The role of arbuscular mycorrhizas in reducing soil nutrient loss. Trends in Plant Science 20, 283-290.

Cordell, D., Drangert, J.O., White, S., 2009. The story of phosphorus: Global food security and food for thought. Global Environmental Change-Human and Policy Dimensions 19, 292-305.

Corkidi, L., Merhaut, D.J., Allen, E.B., Downer, J., Bohn, J., Evans, M., 2011. Effects of mycorrhizal colonization on nitrogen and phosphorus leaching from nursery containers. Hortscience 46, 1472-1479.

Daniel, T., DeLaune, P., 2009. Total phosphorus and total dissolved phosphorus in water samples. Methods of Phosphorus Analysis for Soils, Sediments, Residuals, and Waters Second Edition, 113.

Di, H.J., Cameron, K.C., 2002. Nitrate leaching in temperate agroecosystems: sources, factors and mitigating strategies. Nutrient Cycling in Agroecosystems 64, 237-256.

Douds Jr, D.D., Millner, P.D., 1999. Biodiversity of arbuscular mycorrhizal fungi in agroecosystems. Agriculture, Ecosystems and Environment 74, 77-93.

Flisch, R., Sinaj, S., Charles, R., Richner, W., 2009. GRUDAF 2009 - Grundlagen für die Düngung im Acker- und Futterbau. AGRARForschung 16, 1-97. 
Köhl et al.

Forschungsanstalt Agroscope Reckenholz-Tänikon ART, Forschungsanstalt Agroscope ChanginsWädenswil ACW, 1996. Schweizerische Referenzmethoden der Forschungsanstalten Agroscope. Band 1 Boden- und Substratuntersuchungen zur Düngeberatung (Acker-, Futter-, Obst-, Wein- und Gartenbau). Änderungen 1997-2012. Forschungsanstalten ART, ACW, Zürich.

Hart, M.M., Reader, R.J., 2002. Host plant benefit from association with arbuscular mycorrhizal fungi: variation due to differences in size of mycelium. Biology and Fertility of Soils 36, 357-366.

Havlin, J., Beaton, J.D., Tisdale, S.L., Nelson, W.L., 2005. Soil fertility and fertilizers: An introduction to nutrient management, 7th ed. Pearson Prentice Hall, Upper Saddle River, New Jersey, USA.

Herzog, F., Prasuhn, V., Spiess, E., Richner, W., 2008. Environmental cross-compliance mitigates nitrogen and phosphorus pollution from Swiss agriculture. Environmental Science and Policy 11, 655668.

Jakobsen, I., Abbott, L.K., Robson, A.D., 1992. External hyphae of vesicular-arbuscular mycorrhizal fungi associated with Trifolium subterraneum L. 1. Spread of hyphae and phosphorous inflow into roots. New Phytologist 120, 371-380.

Jansa, J., Mozafar, A., Frossard, E., 2005. Phosphorus acquisition strategies within arbuscular mycorrhizal fungal community of a single field site. Plant and Soil 276, 163-176.

Jansa, J.J., Mozafar, A.M., Anken, T.A., Ruh, R.R., Sanders, I.S., Frossard, E.F., 2002. Diversity and structure of AMF communities as affected by tillage in a temperate soil. Mycorrhiza 12, 225-234.

Joergensen, R.G., 1996. The fumigation-extraction method to estimate soil microbial biomass: calibration of the $k_{E C}$ value. Soil Biology and Biochemistry 28, 25-31.

Joergensen, R.G., Mueller, T., 1996. The fumigation-extraction method to estimate soil microbial biomass: calibration of the $k_{E N}$ value. Soil Biology and Biochemistry 28, 33-37. 
Köhl et al.

Jung, J., 1972. Factors determining leaching of nitrogen from soil, including some aspects of maintenance of water-quality. Qualitas Plantarum Et Materiae Vegetabiles 21, 343-366.

Kim, K.Y., Jordan, D., McDonald, G.A., 1998. Effect of phosphate-solubilizing bacteria and vesiculararbuscular mycorrhiza on tomato growth and soil microbial activity. Biology and Fertility of Soils 26, 79-87.

Knacker, T., van Gestel, C.A.M., Jones, S.E., Soares, A.M.V.M., Schallnaß, H.-J., Förster, B., Edwards, C.A., 2004. Ring-testing and field-validation of a terrestrial model ecosystem (TME) - an instrument for testing potentially harmful substances: conceptual approach and study design. Ecotoxicology 13, 927.

Koerselman, W., Meuleman, A.F.M., 1996. The vegetation N:P ratio: a new tool to detect the nature of nutrient limitation. Journal of Applied Ecology 33, 1441-1450.

Köhl, L., Lukasiewicz, C.E., van der Heijden, M.G.A., 2015. Establishment and effectiveness of inoculated arbuscular mycorrhizal fungi in agricultural soils. Plant, Cell and Environment (in press).

Köhl, L., Oehl, F., van der Heijden, M.G.A., 2014. Agricultural practices indirectly influence plant productivity and ecosystem services through effects on soil biota. Ecological Applications 24, 1842 1853.

Koide, R.T., Li, M.G., 1989. Appropriate controls for vesicular arbuscular mycorrhiza research. New Phytologist 111, 35-44

Krom, M.D., 1980. Spectrophotometric determination of ammonia: a study of a modified Berthelot reaction using salicylate and dichloroisocyanurate. Analyst 105, 305-316.

Ledgard, S.F., Giller, K.E., 1995. Atmospheric $\mathrm{N}_{2}$ fixation as an alternative N source, In: Bacon, P.E. (Ed.), Nitrogen fertilization in the environment. Marcel Dekker, Inc., New York, USA, pp. 443-486. 
Köhl et al.

Lehmann, A., Veresoglou, S.D., Leifheit, E.F., Rillig, M.C., 2013. Arbuscular mycorrhizal influence on zinc nutrition in crop plants - A meta-analysis. Soil Biology and Biochemistry.

Loiseau, P., Carrère, P., Lafarge, M., Delpy, R., Dublanchet, J., 2001. Effect of soil-N and urine-N on nitrate leaching under pure grass, pure clover and mixed grass/clover swards. European Journal of Agronomy 14, 113-121.

Marschner, P., Baumann, K., 2003. Changes in bacterial community structure induced by mycorrhizal colonisation in split-root maize. Plant and Soil 251, 279-289.

Marschner, P., Timonen, S., 2005. Interactions between plant species and mycorrhizal colonization on the bacterial community composition in the rhizosphere. Applied Soil Ecology 28, 23-36.

McGonigle, T.P., Miller, M.H., Evans, D.G., Fairchild, G.L., Swan, J.A., 1990. A new method which gives an objective-measure of colonization of roots by vesicular arbuscular mycorrhizal fungi. New Phytologist 115, 495-501.

Nyfeler, D., 2009. Productivity and nitrogen utilisation in productive agricultural grassland: effects of species combinations, species proportions and nitrogen fertilisation. ETH, Zürich.

Owusu-Bennoah, E., Mosse, B., 1979. Plant growth responses to vesicular-arbuscular mycorrhiza. XI. Field inoculation responses in barley, lucerne and onion. New Phytologist 83, 671-679.

R Core Team, 2013. R: A language and environment for statistical computing, Vienna, Austria.

Ravnskov, S., Jakobsen, I., 1995. Functional compatibility in arbuscular mycorrhizas measured as hyphal P transport to the plant. New Phytologist 129, 611-618.

Rillig, M.C., Mummey, D.L., 2006. Mycorrhizas and soil structure. New Phytologist 171, 41-53. 
Köhl et al.

Säle, V., Aguilera, P., Laczko, E., Mäder, P., Berner, A., Zihlmann, U., van der Heijden, M.G.A., Oehl, F., 2015. Impact of conservation tillage and organic farming on the diversity of arbuscular mycorrhizal fungi. Soil Biology and Biochemistry 84, 38-52.

Schenck, N.C., Smith, G.S., 1982. Responses of six species of vesicular-arbuscular mycorrhizal fungi and their effects on soybean at four soil temperatures. New Phytologist 92, 193-201.

Scherer-Lorenzen, M., Palmborg, C., Prinz, A., Schulze, E.D., 2003. The role of plant diversity and composition for nitrate leaching in grasslands. Ecology 84, 1539-1552.

Scholefield, D., Tyson, K.C., Garwood, E.A., Armstrong, A.C., Hawkins, J., Stone, A.C., 1993. Nitrate leaching from grazed grassland lysimeters: effects of fertilizer input, field drainage, age of sward and patterns of weather. Journal of Soil Science 44, 601-613.

Sieverding, E., da Silva, G.A., Berndt, R., Oehl, F., 2014. Rhizoglomus, a new genus of the Glomeraceae. Mycotaxon 129, 373-386.

Simmelsgaard, S.E., 1998. The effect of crop, N-level, soil type and drainage on nitrate leaching from Danish soil. Soil Use and Management 14, 30-36.

Sims, J.T., Simard, R.R., Joern, B.C., 1998. Phosphorus loss in agricultural drainage: historical perspective and current research. Journal of Environmental Quality 27, 277-293.

Smith, F.A., Jakobsen, I., Smith, S.E., 2000. Spatial differences in acquisition of soil phosphate between two arbuscular mycorrhizal fungi in symbiosis with Medicago truncatula. New Phytologist 147, 357366.

Smith, S.E., Read, D., 2008. Mycorrhizal Symbiosis 3rd ed. Academic Press, Elsevier Ltd., Oxford. 
Köhl et al.

Suter, D., Frick, R., Hirschi, H., Aebi, P., 2015. Prüfung von Italienischem Raigras: Bewährungsprobe für 37 Sorten. Agrarforschung Schweiz 6, 248-255.

Taylor, J., Harrier, L., 2000. A comparison of nine species of arbuscular mycorrhizal fungi on the development and nutrition of micropropagated Rubus idaeus L. cv. Glen Prosen (Red Raspberry). Plant and Soil 225, 53-61.

van der Heijden, M.G.A., 2010. Mycorrhizal fungi reduce nutrient loss from grassland ecosystems. Ecology 91, 1163-1171.

van der Heijden, M.G.A., Martin, F.M., Selosse, M.-A., Sanders, I.R., 2015. Mycorrhizal ecology and evolution: the past, the present, and the future. New Phytologist 205, 1406-1423.

van der Heijden, M.G.A., Streitwolf-Engel, R., Riedl, R., Siegrist, S., Neudecker, A., Ineichen, K., Boller, T., Wiemken, A., Sanders, I.R., 2006. The mycorrhizal contribution to plant productivity, plant nutrition and soil structure in experimental grassland. New Phytologist 172, 739-752.

Vance, C.P., 2001. Symbiotic nitrogen fixation and phosphorus acquisition. Plant nutrition in a world of declining renewable resources. Plant Physiology 127, 390-397.

Vance, E.D., Brookes, P.C., Jenkinson, D.S., 1987. An extraction method for measuring soil microbial biomass C. Soil Biology and Biochemistry 19, 703-707.

Verbruggen, E., Kiers, E.T., Bakelaar, P.C., Röling, W.M., van der Heijden, M.G.A., 2012. Provision of contrasting ecosystem services by soil communities from different agricultural fields. Plant and Soil $350,43-55$

Veresoglou, S.D., Shaw, L.J., Hooker, J.E., Sen, R., 2012. Arbuscular mycorrhizal modulation of diazotrophic and denitrifying microbial communities in the (mycor)rhizosphere of Plantago lanceolata. Soil Biology and Biochemistry 53, 78-81. 
Köhl et al.

Vierheilig, H., Coughlan, A.P., Wyss, U., Piche, Y., 1998. Ink and vinegar, a simple staining technique for arbuscular-mycorrhizal fungi. Applied Environmental Microbiology 64, 5004-5007.

Villegas, J., Fortin, J., 2001. Phosphorus solubilization and pH changes as a result of the interactions between soil bacteria and arbuscular mycorrhizal fungi on a medium containing $\mathrm{NH}_{4}{ }^{+}$as nitrogen source. Canadian Journal of Botany 79, 865-870.

Villegas, J., Fortin, J., 2002. Phosphorus solubilization and $\mathrm{pH}$ changes as a result of the interactions between soil bacteria and arbuscular mycorrhizal fungi on a medium containing $\mathrm{NO}_{3}{ }^{-}$as nitrogen source. Canadian Journal of Botany 80, 571-576.

Wagg, C., Jansa, J., Schmid, B., van der Heijden, M.G.A., 2011a. Belowground biodiversity effects of plant symbionts support aboveground productivity. Ecology Letters 14, 1001-1009.

Wagg, C., Jansa, J., Stadler, M., Schmid, B., van der Heijden, M., 2011b. Mycorrhizal fungal identity and diversity relaxes plant-plant competition. Ecology 92, 1303-1313.

Walder, F., van der Heijden, M.G.A., 2015. Regulation of resource exchange in the arbuscular mycorrhizal symbiosis. Nature Plants 1, 15159.

Watanabe, F.S., Olsen, S.R., 1965. Test of an ascorbic acid method for determining phosphorus in water and $\mathrm{NaHCO}_{3}$ extracts from soil. Soil Science Society of America Journal 29, 677-678.

Watts-Williams, S., Cavagnaro, T., 2014. Nutrient interactions and arbuscular mycorrhizas: a metaanalysis of a mycorrhiza-defective mutant and wild-type tomato genotype pair. Plant and Soil, 1-14.

Weaver, D., Ritchie, G., Anderson, G., Deeley, D., 1988. Phosphorus leaching in sandy soils .I. Shortterm effects of fertilizer applications and environmental conditions. Soil Research 26, 177-190. 
Köhl et al.

Figure 1 Percentage of total root length colonized (\%) by AM fungi and nitrogen and carbon of the microbial biomass (mg per $\mathrm{kg}$ of dry soil) of microcosms planted with Lolium or Trifolium and inoculated with a non-mycorrhizal control inoculum or three different AM fungal species: $\mathrm{Cc}=$ Claroideoglomus claroideum, Fm=Funneliformis mosseae, Ri=Rhizoglomus irregulare. Total root length colonized by AM fungi (\%) is presented as the sum of the percentages of root length colonized by vesicles (black), arbuscules (grey) and hyphae (white). Bars are means of eight (Trifolium) and ten (Lolium) replicates \pm SEM. Asterisks represent significant differences between the non-mycorrhizal control and mycorrhizal plants $\left(\mathrm{p}<0.001 * * *,<0.01 * *,<0.05^{*}\right)$. Means of the mycorrhizal treatments with the same letter are not significantly different at the 0.05 level using Tukey HSD test.

Figure 2 Total biomass (roots and shoots) (g) of Lolium and Trifolium inoculated with a nonmycorrhizal control inoculum or three different AM fungal species: $\mathrm{Cc}=$ Claroideoglomus claroideum, $\mathrm{Fm}=$ Funneliformis mosseae, $\mathrm{Ri}=$ Rhizoglomus irregulare. Means of eight $($ Trifolium $)$ and ten $($ Lolium $)$ replicates \pm SEM are shown. Asterisks indicate that the control treatment is significantly different from the mycorrhizal treatments $\left(\mathrm{p}<0.001 * * *,<0.01 * *,<0.05^{*}\right)$. Mycorrhizal treatment means with the same letter are not significantly different at the 0.05 level using Tukey HSD test.

Figure 3 Total nutrient content (mg) of Lolium and Trifolium plants (roots and shoots) inoculated with a non-mycorrhizal control inoculum (Control) or three different AM fungal species: $\mathrm{Cc}=$ Claroideoglomus claroideum, $\mathrm{Fm}=$ Funneliformis mosseae, $\mathrm{Ri}=$ Rhizoglomus irregulare . Means of eight (Trifolium) and ten (Lolium) replicates \pm SEM are shown. Asterisks indicate that the control treatment is significantly different from the mycorrhizal treatments $\left(\mathrm{p}<0.001^{* * *},<0.01^{* *},<0.05^{*}\right)$. Mycorrhizal treatment means with the same letter are not significantly different at the 0.05 level using Tukey HSD test.

Figure 4 Nutrients leached from pots planted with Lolium or Trifolium after a leaching inducing rain simulation. All P fractions besides phosphate in the leachate are summarized as "unreactive P". Pots were inoculated with a non-mycorrhizal control inoculum or three different AMF species: $\mathrm{Cc}=$ Claroideoglomus claroideum, $\mathrm{Fm}=$ Funneliformis mosseae, $\mathrm{Ri}=$ Rhizoglomus irregulare . Means of eight 
Köhl et al.

(Trifolium) and ten (Lolium) replicates \pm SEM are shown. Asterisks indicate that the control treatment is significantly different from the mycorrhizal treatments $\left(\mathrm{p}<0.001^{* * *},<0.01^{* *},<0.05^{*}\right)$. Mycorrhizal treatment means with the same letter are not significantly different at the 0.05 level using Tukey HSD test. 
Köhl et al.

Table 1 Results of t-tests or Wilcoxon rank sum test $\left({ }^{a}\right)$ (if errors were not normal distributed) comparing leaching results of the non-mycorrhizal control with results of mycorrhizal microcosms for each AM fungal species separately. Lolium $(\mathrm{df}=18)$ and Trifolium $(\mathrm{df}=14)$ microcosms were analyzed separately. Values in bold are significantly different $(\mathrm{P}<0.05)$.

\begin{tabular}{|c|c|c|c|c|c|c|c|c|c|c|c|c|}
\hline \multirow{3}{*}{ Response } & \multicolumn{6}{|c|}{ Lolium } & \multicolumn{6}{|c|}{ Trifolium } \\
\hline & \multicolumn{2}{|c|}{ Cc } & \multicolumn{2}{|c|}{ Fm } & \multicolumn{2}{|c|}{$\mathbf{R i}$} & \multicolumn{2}{|c|}{$\mathrm{Cc}$} & \multicolumn{2}{|c|}{ Fmc } & \multicolumn{2}{|c|}{$\mathbf{R i}$} \\
\hline & $\mathbf{t}$ & $\mathbf{p}$ & $\mathbf{t}$ & $\mathbf{p}$ & $\mathbf{t} / \mathbf{W}^{\mathbf{a}}$ & $\mathbf{p}$ & $\mathbf{t}$ & $\mathbf{p}$ & $\mathbf{t}$ & $\mathbf{p}$ & $\mathbf{t}$ & $\mathbf{p}$ \\
\hline total mineral $\mathrm{N}$ & 3.23 & 0.005 & -0.51 & 0.614 & 2.97 & 0.008 & 19.47 & 0.000 & 20.76 & 0.000 & 20.87 & 0.000 \\
\hline $\mathrm{NH}_{4}^{+\mathbf{a}}$ & 2.75 & 0.013 & -0.84 & 0.410 & 22 & 0.035 & -3.48 & 0.004 & -6.07 & 0.000 & -3.87 & 0.002 \\
\hline $\mathrm{NO}^{3-\mathbf{a}}$ & 1.47 & 0.160 & -0.33 & 0.745 & 13 & 0.005 & 19.54 & 0.000 & 20.86 & 0.000 & 21.01 & 0.000 \\
\hline total dissolved $\mathrm{P}$ & -0.03 & 0.978 & -2.67 & 0.015 & 0.69 & 0.499 & -0.47 & 0.643 & -2.03 & 0.062 & -0.29 & 0.774 \\
\hline $\mathrm{PO}_{4}{ }^{3-}$ & -0.75 & 0.462 & -2.74 & 0.013 & 1.07 & 0.299 & 1.69 & 0.114 & 0.96 & 0.352 & 0.60 & 0.556 \\
\hline unreactive $\mathrm{P}$ & 2.50 & 0.022 & -0.21 & 0.837 & -0.85 & 0.405 & -3.11 & 0.008 & -5.60 & 0.000 & -1.76 & 0.101 \\
\hline leachate volume & -2.65 & 0.016 & -0.67 & 0.513 & -3.23 & 0.005 & 1.27 & 0.225 & 1.11 & 0.284 & 1.55 & 0.145 \\
\hline
\end{tabular}




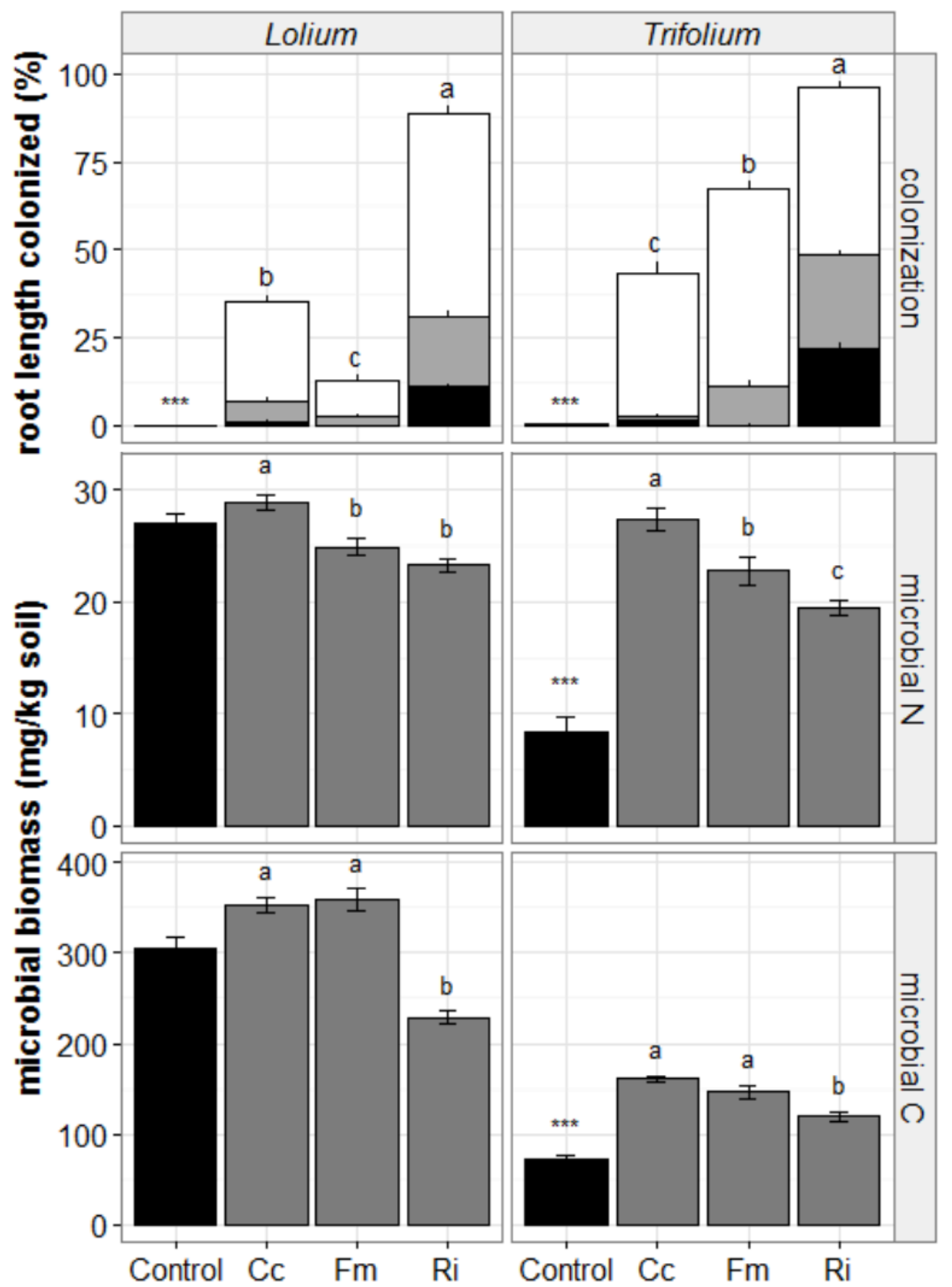




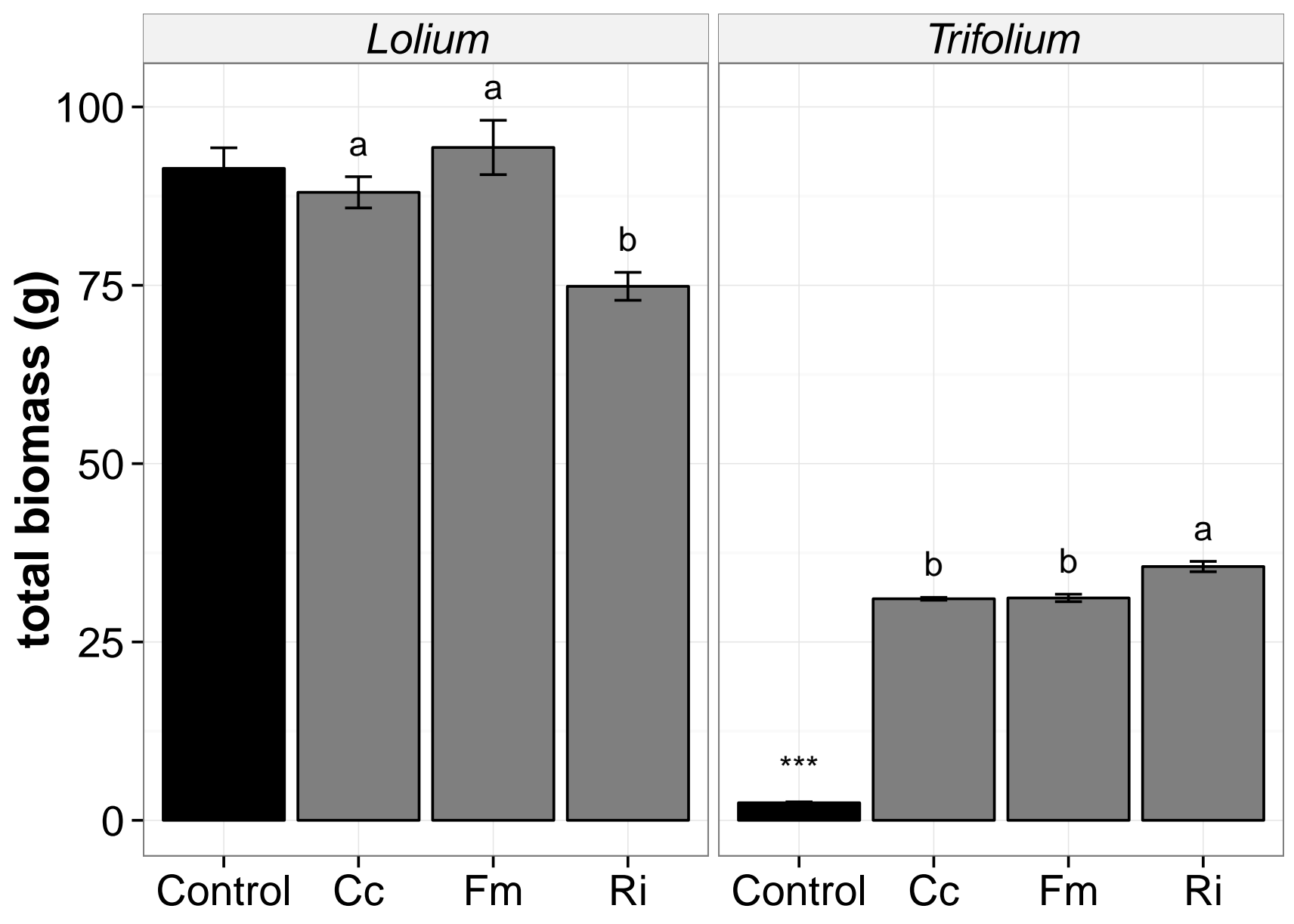


